\title{
INTERNATIONAL YEAR OF CHEMISTRY
}

\section{K. Isaev}

The present year has been proclaimed the International Year of Chemistry by the United Nations. The idea arose in 2006 at a meeting of the executive committee of IUPAC, the International Union of Pure and Applied Chemistry, and the developed plan was endorsed by UNESCO. The unifying theme for the celebration is "Chemistry - our life, our future." This is precisely why the World Metrology Day 2011 had as its slogan "Chemical measurements for our life, our future." The messages of the Director of the International Bureau of Weights and Measures (IBWM), Prof. M. Kühne, and the Director of the International Bureau of Legal Metrology (BIML), Stephen Patoray were read to the Seventh Moscow International Forum May 17-19, 2011 and published in the mass media (see Measurement Techniques, No. 5 (2011)).

Metrologists say that, "Metrology is part of our lives." Today everybody can say that, "Chemistry is part of our lives." Indeed, chemistry is a foundation science, on which the quality of our lives depends significantly. Chemistry touches food products, the environment, pharmaceuticals, and various areas of technology. The role of metrology in chemistry has been fully told in an article by L. K. Isaev and R. Kaarls, members of the IBWM [L. K. Isaev and R. Kaarls, "Metrology in Chemistry," Zavodskaya Laboratoriya. Diagnostika Materialov, 73, No. 1, pp. 110-112 (2007)]. Furthermore, Dr. R. Kaarls is the president of the Consultative Committee for Amount of Substance - Metrology in Chemistry (CCQM) founded in 1993. The committee has carrying out a program during 2009-2012, whose major themes are:

1) expansion of activities in the analysis of gases for ozone and some greenhouse gases in order to evaluate climate change and air quality;

2) expansion of activities in organic analysis, specifically, the development of supporting substances (purity of organic components), including the use of new advances in the creation of methods for the organic analysis of food products, health, and legal medicine;

3) study of the requirements and achievements in bioanalysis; and

4) establishment and maintenance of cooperation with other intergovernmental and international organizations interested in solving metrology problems in chemistry, which already concern the CCQM, International Bureau of Weights and Measures, and national metrological institutes, including the area of gene modification.

While in 2006, 3559 of 18443 citations in the database of calibration and measurement capabilities related to chemistry, such citations were already 4841 of 24047 in 2010.

The year 2011 was also proclaimed as Mikhail Lomonosov Year by UNESCO in recognition of the achievements of this world-class scientist on the occasion of the $300^{\text {th }}$ anniversary of this birth. Lomonosov was a scientist and encylopedist who gave impetus to the development of atomic and molecular theory, developed the principle of the conservation of motion and matter, laid the foundation for the study of light and physical chemistry, discovered the atmosphere on Venus, created Moscow University, and also was a poet, historian artist, and founder of the modern Russian literary language. It was Lomonosov in 1746 who was the first to give lectures at the Academy of Sciences in Russian. His life can be divided into three periods: prior to his founding a chemical laboratory in 1748, during his chemistry investigations, and work after 1757 on natural and applied sciences including metallurgy, mine engineering, optics, maritime transport, geography, meteorology, and astronomy.

Hence, the Editorial Board of Izmeritel'naya Tekhnika has decided to devote this issue entirely to the International Year of Chemistry and to measurements carried out in this area. The Board plans to return to this subject in subsequent issues of the journal.

Doctor of Technical Sciences, Member of the International Bureau of Weights and Measures. Translated from Izmeritel'naya Tekhnika, Vol. 54, No. 9, p. 3, September, 2011. 